\title{
Performa Kambing yang Diberi Kulit Buah Kakao Terfermentasi
}

\author{
Goat Performance Fed with Fermented Cocoa Pod Husk
}

\author{
Suparjo $^{a, *}$, K. G. Wiryawan ${ }^{\text {b }}$, E. B. Laconi ${ }^{b}$, \& D. Mangunwidjaja ${ }^{c}$ \\ aLaboratorium Makanan Ternak Fakultas Peternakan, Universitas Jambi \\ Jln. Jambi-Ma. Bulian Km 15 Mendalo Darat Jambi \\ bDepartemen Ilmu Nutrisi dan dan Teknologi Pakan, Fakultas Peternakan, Institut Pertanian Bogor \\ Jln. Agatis, Kampus IPB Darmaga Bogor 16680 \\ 'Departemen Teknologi Ilmu Pertanian, Fakultas Teknologi Pertanian, Institut Pertanian Bogor \\ Jln. Kamper, Kampus IPB Darmaga Bogor 16680 \\ (Diterima 26 April 2010; disetujui 16-01-2011)
}

\begin{abstract}
Utilization of cocoa pod husk (CPH) as feedstuff needs pretreatment to increase its nutrients availability. Bioconversion with Phanerochaete chrysosporium changes its structure by breaking down the linkage between lignin and structural carbohydrates. This experiment was aimed to evaluate the quality of fermented CPH biomass as feed for goats. The experimental treatments i.e.: $\mathrm{A}=30 \%$ of fresh napier grass (RG) $+50 \%$ of dried RG $+20 \%$ of concentrate; $B=30 \%$ of fresh RG $+30 \%$ of dried RG $+40 \%$ of concentrate; $C=30 \%$ of fresh RG $+30 \%$ of $\mathrm{CPH}+40 \%$ of concentrate; $\mathrm{D}=30 \%$ of fresh RG $+30 \%$ of fermented $\mathrm{CPH}+40 \%$ of concentrate and $\mathrm{E}=30 \%$ of fresh $\mathrm{RG}+50 \%$ of fermented $\mathrm{CPH}$ $+20 \%$ of concentrate. The treatments were allocated in a randomized block design with three replications. Feed intake, body weight gain and ration efficiency were measured. The use of fermented CPH at the level of $30 \%$ had higher $(\mathrm{P}<0.05)$ feed intake $\left(560.33 \mathrm{~g} \mathrm{day}^{-1}\right)$, body weight gain $\left(101.79 \mathrm{~g} \mathrm{head}^{-1}\right.$ day $^{-1}$ ), and feed conversion (5.50) compared to other treatments. In conclusion that the use of $30 \%$ fermented $\mathrm{CPH}$ in the ration showed the best body weight gain and feed efficiency.
\end{abstract}

Key words: cocoa pod husk, napier grass, Phanerochaete chrysosporium, bioconversion, goat

\section{PENDAHULUAN}

Kulit buah kakao merupakan hasil ikutan tanaman kakao dengan proporsi mencapai $75 \%$ dari buah segar. Kulit buah kakao segar mengandung kadar air yang tinggi sehingga mudah menjadi busuk. Penggunaan kulit buah kakao sebagai mulsa yang disebar di sekeliling tanaman dapat menjadi tempat tumbuh cendawan Phytopthora palmivora yang menyebabkan black pod diseases. Kenyataan ini menimbulkan masalah dalam penanganan hasil ikutan tanaman kakao karena secara langsung dapat menurunkan produksi kakao. Salah satu alternatif yang mungkin adalah pemanfaatan kulit buah kakao sebagai bahan pakan.

Efektivitas pemanfaatan kulit buah kakao dibatasi oleh komposisi nutrisi yang kurang baik, terutama kandungan protein yang rendah dan komponen lignoselulosa yang tinggi (Alemawor et al., 2009). Nilai manfaat hasil ikutan pertanian sebagai bahan pakan dapat ditingkatkan dengan memberikan perlakuan pendahuluan, baik secara fisik, kimia maupun biologis (Sun \& Cheng, 2002). Perlakuan pendahuluan bertujuan untuk menghilangkan, memutus atau mengurangi keeratan ikatan antara selulosa dan hemiselulosa dengan lignin. Ikatan lignoselulosa dapat diputus oleh ligninase seperti lignin peroksidase $(\mathrm{LiP})$ dan mangan peroksidase $(\mathrm{MnP})$ (Takano et al., 2004). Enzim LiP dan MnP dihasilkan oleh beberapa organisme termasuk diantaranya Phanerochaete chrysosporium. P. chrysosporium dalam proses biokonversi antara lain mampu mendegradasi komponen lignin terlebih dahulu diikuti dengan komponen selulosa (de Koker et al., 2003), mempunyai fase lag yang cepat sekitar 0-3 hari (Shi et al., 2009), dan mampu tumbuh optimal pada suhu $40^{\circ} \mathrm{C}$ (Singh \& Chen, 2008), sehingga cocok digunakan dalam proses fermentasi yang banyak menghasilkan panas.

Biokonversi dengan $P$. chrysosporium mampu mengurangi keeratan ikatan dan kandungan lignin yang dapat meningkatkan kualitas kulit buah kakao. Kandungan total digestible nutrient (TDN) dan protein kulit buah kakao hampir sama dengan rumput gajah. Penelitian ini bertujuan mengkaji penggunaan kulit buah kakao yang difermentasi dengan $P$. chrysosporium terhadap performa ternak kambing.

\footnotetext{
a Korespondensi:

E-mail: jatayu66@yahoo.com
} 


\section{MATERI DAN METODE}

\section{Pengolahan Kulit Buah Kakao}

Kulit buah kakao (KBK) segar dicacah dan dikeringkan hingga kadar bahan kering diperkirakan mencapai 35\%. Setiap $100 \mathrm{~kg}$ KBK kering ditempatkan pada terpal plastik dan ditambahkan 100 ppm Mn dan 1190 ppm Ca (dasar bahan kering). KBK diinokulasi dengan $P$. chrysosporium sebanyak 0,9\% dari bahan kering (Bonnen et al., 1994); dan dicampur secara merata. Kapang $P$. chrysosporium IFO 31249 diperoleh dari Pusat Penelitian Kimia-LIPI Kawasan PUSPIPTEK Serpong. Biakan starter kapang ditumbuhkan pada jewawut selama 10 hari. Campuran KBK dan kapang difermentasi selama 10 hari (Suparjo et al., 2009). Kulit buah kakao hasil fermentasi merupakan salah satu bahan penyusun ransum.

\section{Pemeliharaan Ternak}

Ternak yang digunakan adalah 15 ekor kambing lokal Jambi jantan dengan bobot badan awal 11,6 $6 \pm 1,5 \mathrm{~kg}$. Komposisi bahan penyusun ransum kambing percobaan ditunjukkan dalam Tabel 1. Kadar mineral ransum diperkaya dengan penambahan $\mathrm{MnSO}_{4} \cdot \mathrm{H}_{2} \mathrm{O}$ dan $\mathrm{CaCl}_{2}$. Ransum disusun untuk mencapai pertambahan bobot badan (PBB) $100 \mathrm{~g}$ hari, dengan kebutuhan protein sebesar $50 \mathrm{~g}$ dan TDN sebesar $359 \mathrm{~g}^{\text {hari-1 }}$ (NRC, 1981). Estimasi kemampuan konsumsi bahan kering pakan oleh kambing sebesar $645 \mathrm{~g}$ ekor $^{-1}$ hari $^{-1}$. Pakan yang diberikan berupa rumput gajah segar dan rumput gajah kering, KBK terfermentasi dan konsentrat.

Penelitian dilakukan dalam tiga periode, yaitu adaptasi, pendahuluan, dan koleksi data. Periode adap- tasi dilakukan untuk penyesuaian ternak dengan lingkungan percobaan. Periode adaptasi dilakukan selama 30 hari, periode pendahuluan 15 hari dan periode koleksi data selama 28 hari. Pakan pada periode koleksi data diberikan ad libitum yang jumlahnya ditentukan berdasarkan konsumsi pakan bebas pada periode pendahuluan. Air minum diberikan ad libitum.

\section{Rancangan Percobaan}

Percobaan menggunakan rancangan acak kelompok (RAK) dengan 5 perlakuan dan 3 kelompok. Jenis ransum berfungsi sebagai perlakuan dan perbedaaan bobot badan kambing sebagai kelompok. Peubah yang diukur dan dianalisa pada percobaan ini adalah konsumsi pakan dan nutrien (g ekor ${ }^{-1}$ hari $\left.{ }^{-1}\right)$, PBB harian $\left(\mathrm{g} \mathrm{hari}^{-1}\right)$, dan efisiensi ransum. Data dianalisa dengan sidik ragam dan pengujian nilai tengah perlakuan menggunakan uji jarak berganda Duncan.

\section{HASIL DAN PEMBAHASAN}

\section{Karakteristik Biomasa KBK dan Ransum Perlakuan}

Fermentasi dengan $P$. chrysosporium meningkatkan kandungan protein dan selulosa KBK (Tabel 2). Kandungan protein kasar KBK (8,69\%) setara dengan protein kasar rumput gajah (8,56\%). Fermentasi meningkatkan kandungan protein kasar KBK menjadi 13,84\% atau meningkat sebesar 59,31\%. Perubahan kandungan protein kasar substrat bervariasi tergantung jenis bahan dan mikroorganisme yang digunakan dalam fermentasi. Fermentasi KBK dengan Pleurotus ostreatus yang dilakukan oleh Alemawor et al. (2009) meningkatkan

Tabel 1 Komposisi bahan pakan dan kandungan nutrien ransum percobaan (\%)

\begin{tabular}{|c|c|c|c|c|c|}
\hline \multirow{2}{*}{ Bahan } & \multicolumn{5}{|c|}{ Perlakuan } \\
\hline & A & B & $\mathrm{C}$ & $\mathrm{D}$ & $\mathrm{E}$ \\
\hline Rumput gajah & 80,0 & 60,0 & 30,0 & 30,0 & 30,0 \\
\hline Kulit buah kakao (KBK) & 0,0 & 0,0 & 30,0 & 0,0 & 0,0 \\
\hline Kbk fermentasi & 0,0 & 0,0 & 0,0 & 30,0 & 50,0 \\
\hline Dedak halus & 9,5 & 29,5 & 29,5 & 29,5 & 9,5 \\
\hline Jagung & 2,0 & 2,0 & 2,0 & 2,0 & 2,0 \\
\hline Bungkil kelapa & 2,0 & 2,0 & 2,0 & 2,0 & 2,0 \\
\hline Bungkil kedelai & 2,0 & 2,0 & 2,0 & 2,0 & 2,0 \\
\hline Molases & 3,2 & 3,2 & 3,2 & 3,2 & 3,2 \\
\hline Garam & 0,5 & 0,5 & 0,5 & 0,5 & 0,5 \\
\hline Feedmix & 0,8 & 0,8 & 0,8 & 0,8 & 0,8 \\
\hline Total & 100,0 & 100,0 & 100,0 & 100,0 & 100,0 \\
\hline \multicolumn{6}{|c|}{ Kandungan nutrien ransum penelitian (\% BK) } \\
\hline Bahan kering & 84,9 & 86,3 & 86,3 & 86,3 & 84,8 \\
\hline Protein kasar & 10,2 & 11,3 & 11,3 & 12,9 & 12,9 \\
\hline TDN & 58,9 & 62,4 & 61,6 & 62,6 & 59,3 \\
\hline
\end{tabular}

Keterangan: $\mathrm{A}=80 \%$ rumput gajah $(\mathrm{RG})+20 \%$ konsentrat; $\mathrm{B}=60 \% \mathrm{RG}+40 \%$ konsentrat; $\mathrm{C}=30 \% \mathrm{RG}+30 \% \mathrm{kulit}$ buah kakao (KBK) $+40 \%$ konsentrat; $\mathrm{D}=30 \% \mathrm{RG}+30 \% \mathrm{KBK}$ fermentasi $+40 \%$ konsentrat; $\mathrm{C}=30 \% \mathrm{RG}+50 \% \mathrm{KBK}$ fermentasi $+20 \%$ konsentrat. 
kandungan protein kasar sebesar 39,9\%. Iyayi (2004) melaporkan bahwa peningkatan kandungan protein substrat setelah fermentasi terjadi karena biokonversi gula menjadi protein miselium. Sekresi enzim ekstraseluler oleh $P$. chrysosporium turut berperan dalam meningkatkan kandungan protein biomasa KBK.

Kandungan serat kasar KBK lebih tinggi (42,55\%) dibanding serat kasar rumput gajah (32,47\%). Fermentasi KBK menurunkan kandungan serat kasar (34,36\%) hampir sama dengan kandungan serat kasar rumput gajah. Penurunan kandungan serat kasar KBK fermentasi disebabkan oleh degradasi komponen dinding sel, yaitu lignin dan hemiselulosa. $P$. chrysosporium dengan bantuan enzim ekstraseluler yang disekresikan mampu merenggangkan ikatan antara lignin dengan polisakarida dan mendegradasi lignin menjadi senyawa yang lebih sederhana.

Rumput gajah merupakan salah satu jenis rumput unggul dengan komposisi kimia yang cukup baik untuk ternak ruminansia. Penggunaan rumput gajah dalam ransum dapat disubstitusi oleh KBK karena memiliki kandungan protein dan TDN yang hampir sama. Fermentasi KBK menyebabkan kandungan proteinnya lebih baik daripada rumput gajah, sedangkan kandungan lignin KBK yang tinggi $(38,45 \%)$ dapat diturunkan dengan fermentasi menjadi $26,63 \%$. Jenis bahan dan perbedaan penggunaan konsentrat menyebabkan komposisi kimia ransum perlakuan bervariasi (Tabel 3).

Tabel 2. Komposisi kimia kulit buah kakao (KBK), KBK fermentasi (KBKF) dan rumput gajah (RG) (\% BK)

\begin{tabular}{|c|c|c|c|}
\hline \multirow{2}{*}{ Komponen bahan pakan } & \multicolumn{3}{|c|}{ Bahan } \\
\hline & KBK & KBKF & RG \\
\hline Bahan kering & 83,79 & 83,66 & 20,12 \\
\hline Abu & 14,61 & 14,75 & 15,65 \\
\hline Protein kasar & 8,69 & 13,84 & 8,56 \\
\hline Serat kasar & 42,55 & 34,36 & 32,47 \\
\hline Lemak kasar & 2,74 & 2,03 & 2,92 \\
\hline Bahan ekstrak tanpa nitrogen (BETN) & 31,41 & 35,02 & 40,39 \\
\hline Total digestible nutrient (TDN)* & 52,88 & 55,31 & 58,99 \\
\hline Neutral detergent fiber (NDF) & 75,36 & 66,39 & 63,00 \\
\hline Acid detergent fiber (ADF) & 68,70 & 63,95 & 46,00 \\
\hline Hemiselulosa & 6,66 & 2,44 & 17,00 \\
\hline Lignin & 38,45 & 26,63 & 15,21 \\
\hline Selulosa & 30,24 & 37,32 & 30,79 \\
\hline
\end{tabular}

Keterangan: ${ }^{*} \mathrm{TDN}=5,31+(0,412 \times \%$ Protein Kasar $)+(0,249 \times \%$ Serat Kasar $)+(1,444 \times \%$ Lemak Kasar $)+(0,937 \times \%$ BETN $)($ Moran, 2005) .

Tabel 3. Komposisi kimia ransum penelitian (\% berdasarkan bahan kering)

\begin{tabular}{|c|c|c|c|c|c|}
\hline \multirow{2}{*}{ Komponen bahan pakan } & \multicolumn{5}{|c|}{ Perlakuan } \\
\hline & $\mathrm{A}$ & B & $\mathrm{C}$ & $\mathrm{D}$ & $\mathrm{E}$ \\
\hline Bahan kering & 82,30 & 84,6 & 85,66 & 86,3 & 84,11 \\
\hline Abu & 15,13 & 14,34 & 13,11 & 12,14 & 12,37 \\
\hline Protein kasar & 10,41 & 11,80 & 11,80 & 12,77 & 12,02 \\
\hline Serat kasar & 27,54 & 21,91 & 28,68 & 23,19 & 28,50 \\
\hline Lemak kasar & 5,46 & 9,13 & 8,77 & 8,41 & 4,42 \\
\hline BETN & 41,45 & 42,81 & 37,64 & 43,49 & 42,69 \\
\hline $\mathrm{TDN}^{*}$ & 63,19 & 68,93 & 65,25 & 69,24 & 63,74 \\
\hline $\mathrm{NDF}$ & 57,51 & 54,11 & 56,69 & 50,09 & 57,04 \\
\hline $\mathrm{ADF}$ & 39,83 & 32,45 & 43,06 & 38,37 & 44,23 \\
\hline Hemiselulosa & 17,68 & 21,67 & 13,62 & 11,73 & 12,82 \\
\hline Lignin & 14,31 & 12,07 & 21,27 & 14,31 & 16,30 \\
\hline Selulosa & 25,52 & 20,38 & 21,79 & 24,06 & 27,93 \\
\hline
\end{tabular}

Keterangan: $\mathrm{A}=80 \%$ rumput gajah $(\mathrm{RG})+20 \%$ konsentrat; $\mathrm{B}=60 \% \mathrm{RG}+40 \%$ konsentrat; $\mathrm{C}=30 \% \mathrm{RG}+30 \% \mathrm{KBK}+40 \% \mathrm{konsentrat}$; $\mathrm{D}=30 \% \mathrm{RG}+30 \%$ kulit buah kakao (KBK) fermentasi + 40\% konsentrat; C=30\% RG +50\% KBK fermentasi + 20\% konsentrat. ${ }^{*} \mathrm{TDN}=5,31+(0,412 \times \%$ Protein Kasar $)+(0,249 \times$ \% Serat Kasar $)+(1,444$ x \% Lemak Kasar $)+(0,937$ x \% BETN) (Moran, 2005). 


\section{Konsumsi Pakan dan Nutrien}

Konsumsi pakan dapat diekspresikan dengan satuan g ekor- $^{-1}$ hari $^{-1}$ (van Hao \& Liden, 2001), $\mathrm{g} \mathrm{kg}^{-1}$ bobot badan hari-1 (Van, et al. 2005), atau $\mathrm{g} \mathrm{kg}^{-1}$ bobot badan metabolik $\left(\mathrm{BB}^{0,75}\right)$ hari $^{-1}$ (Mandal et al., 2005). Rataan konsumsi (Tabel 4) bahan kering selama penelitian berkisar 434-560 $\mathrm{g}$ ekor $^{-1}$ hari $^{-1}$ atau 60-78 $\mathrm{g} \mathrm{kg}^{-1} \mathrm{BB}^{0,75}$ hari $^{-1}$. Konsumsi bahan kering kambing yang dilaporkan oleh beberapa peneliti bervariasi, yaitu 41,5 (Kondo et al., 2004), 54,94 (Katongole et al., 2009), 61,8 (Aregheore, 2006), dan 78,1 $\mathrm{g} \mathrm{kg}^{-1} \mathrm{BB}^{0,75}$ hari-1 (Abdou et al., 2011). Perbedaan konsumsi bahan kering disebabkan oleh kandungan nutrien, terutama kandungan protein dan energi pakan (Negesse et al., 2001), status fisiologis (Fedele et al., 2002), jenis kelamin ternak (Lewis \& Emmans, 2010), dan bahan pakan penyusun ransum (Aregheore, 2006). Pemanfaatan KBK fermentasi (Tabel 1) berperan dalam peningkatan kandungan protein pakan (Tabel 3) yang berimplikasi pada peningkatan konsumsi bahan kering (Tabel 4), tetapi belum menunjukkan perbedaan.

Konsumsi bahan kering perlakuan A dan B lebih rendah dibandingkan perlakuan lain. Hal ini disebabkan sifat amba (bulky) rumput gajah yang menyebabkan peningkatan volume per satuan berat. Coleman dan Moore (2003) menyebutkan bahwa pengaturan konsumsi pakan merupakan interaksi antara karakteristik bahan pakan, rumen dan ternak. Rumput gajah yang amba membatasi kemampuan ternak untuk lebih banyak lagi mengkonsumsi pakan karena kapasitas rumen menjadi terbatas. Yansari et al. (2004) menyebutkan bahwa konsumsi pakan dapat dibatasi oleh kapasitas rumen dan lama pengeluaran digesta dari rumen. Hasil penelitian Toharmat et al. (2006) menunjukkan bahwa berat jenis rumput gajah $\left(0,854 \mathrm{~kg} / \mathrm{dm}^{3}\right)$ lebih kecil dibandingkan kulit buah kakao $\left(1,156 \mathrm{~kg} / \mathrm{dm}^{3}\right)$. Bahan pakan dengan berat jenis yang makin kecil menunjukkan semakin amba sehingga membutuhkan ruang yang lebih besar di dalam rumen ternak.
Konsumsi bahan kering ransum berkisar 3,1\%-4,0\% dari bobot badan. Pakan yang dikonsumsi digunakan untuk hidup pokok dan pertumbuhan atau reproduksi. Konsumsi bahan kering ini sudah memenuhi kebutuhan hidup pokok, yaitu 2,4\%-2,8\% dari bobot badan (NRC, 1981) namun belum mencukupi kebutuhan untuk meningkatkan bobot badan sebesar $100 \mathrm{~g} \mathrm{ekor}^{-1}$ hari $^{-1}$. Kebutuhan bahan kering untuk mencapai PBB $100 \mathrm{~g}$ ekor $^{-1}$ hari $^{-1}$ sebesar $360 \mathrm{~g}$ ditambah dengan kebutuhan untuk hidup pokok yang besarnya tergantung pada bobot badan ternak (Tabel 6). Konsumsi bahan kering di bawah standar kebutuhan ternak sering terjadi karena pakan lebih tahan terhadap pemecahan selama pengunyahan (chewing) yang akan menurunkan kecernaan bahan kering. Coleman \& Moore (2003) menyatakan bahwa kecernaan mempunyai hubungan yang erat dengan konsumsi bahan kering.

Pola konsumsi bahan organik mengikuti pola konsumsi bahan kering. Rataan konsumsi bahan organik selama penelitian berkisar 368-492 $\mathrm{g}_{\text {ekor }}^{-1}$ hari $^{-1}$ atau 51-69 $\mathrm{g} \mathrm{kg}^{-1} \mathrm{BB}^{0,75}$ hari $^{-1}$. Konsumsi bahan organik ini lebih rendah dibandingkan hasil penelitian van Hao \& Liden (2001), yaitu sebesar $565 \mathrm{~g}$ ekor $^{-1}$ hari $^{-1}$. Tuah et al. (1995) melaporkan bahwa konsumsi bahan organik KBK dalam ransum oleh ternak domba sekitar 71,8-95,4 $\mathrm{g} \mathrm{kg}^{-1}$ $\mathrm{BB}^{0,75}$ hari $^{-1}$. Konsumsi bahan organik perlakuan A lebih rendah $(\mathrm{P}<0,05)$ dibandingkan perlakuan lain. Konsumsi bahan organik yang rendah disebabkan konsumsi bahan kering (434 g ekor $^{-1}$ hari $^{-1}$ ) yang rendah dan kandungan abu yang lebih tinggi (15,13\%).

Konsumsi protein berkaitan erat dengan PBB. Protein digunakan untuk pemenuhan hidup pokok, produksi, dan reproduksi. Rataan konsumsi protein selama penelitian berkisar 45-72 $\mathrm{g}_{\text {ekor }}{ }^{-1}$ hari $^{-1}$. Jumlah konsumsi protein ini telah memenuhi estimasi standar kecukupan kebutuhan protein kasar berdasarkan bobot badan untuk mencapai PBB $100 \mathrm{~g}$ hari $^{-1}$, yaitu 56-58 g ekor $^{-1}$ hari $^{-1}$ (Tabel 6), kecuali perlakuan A. Konsumsi protein perlakuan A lebih kecil $(\mathrm{P} \varangle 0,05)$ dibandingkan

Tabel 4. Rataan konsumsi pakan kambing yang diberi perlakuan (g ekor-1 hari-1)

\begin{tabular}{|c|c|c|c|c|c|}
\hline \multirow{2}{*}{ Nutrien } & \multicolumn{5}{|c|}{ Perlakuan } \\
\hline & A & B & $\mathrm{C}$ & $\mathrm{D}$ & E \\
\hline Bahan kering & $434 \pm 8$ & $499 \pm 59$ & $538 \pm 24$ & $560 \pm 57$ & $550 \pm 21$ \\
\hline Bahan organik & $368 \pm 7^{b}$ & $428 \pm 51^{\mathrm{ab}}$ & $467 \pm 21^{\mathrm{ab}}$ & $492 \pm 50^{\mathrm{a}}$ & $482 \pm 16^{a}$ \\
\hline Protein kasar & $45 \pm 1^{\mathrm{b}}$ & $59 \pm 7^{\mathrm{ab}}$ & $63 \pm 3^{a}$ & $72 \pm 7^{a}$ & $66 \pm 15^{\mathrm{a}}$ \\
\hline Lemak kasar & $24 \pm 0^{\mathrm{b}}$ & $46 \pm 5^{a}$ & $47 \pm 2^{\mathrm{a}}$ & $47 \pm 5^{\mathrm{a}}$ & $24 \pm 5^{b}$ \\
\hline Serat kasar & $120 \pm 2^{\mathrm{bc}}$ & $109 \pm 13^{c}$ & $154 \pm 7^{\mathrm{ab}}$ & $130 \pm 13^{\mathrm{abc}}$ & $157 \pm 35^{a}$ \\
\hline TDN & $274 \pm 5^{\mathrm{b}}$ & $344 \pm 41^{\mathrm{ab}}$ & $351 \pm 16^{\mathrm{ab}}$ & $388 \pm 40^{\mathrm{a}}$ & $350 \pm 77^{\mathrm{ab}}$ \\
\hline $\mathrm{NDF}$ & $250 \pm 5$ & $270 \pm 32$ & $305 \pm 14$ & $281 \pm 30$ & $314 \pm 69$ \\
\hline $\mathrm{ADF}$ & $173 \pm 3^{b}$ & $162 \pm 19^{b}$ & $232 \pm 10^{a}$ & $215 \pm 22^{\mathrm{ab}}$ & $243 \pm 54^{a}$ \\
\hline Selulosa & $111 \pm 2^{\mathrm{b}}$ & $102 \pm 12^{\mathrm{b}}$ & $117 \pm 5^{\mathrm{b}}$ & $135 \pm 14^{\mathrm{ab}}$ & $153 \pm 34^{\mathrm{a}}$ \\
\hline Hemiselulosa & $77 \pm 1^{\mathrm{b}}$ & $108 \pm 13^{a}$ & $73 \pm 3^{b}$ & $66 \pm 7^{b}$ & $70 \pm 16^{\mathrm{b}}$ \\
\hline
\end{tabular}

Keterangan: Superskrip berbeda pada baris yang sama menunjukkan berbeda nyata $(\mathrm{P} \varangle$, 05$)$. $\mathrm{A}=80 \%$ rumput gajah $(\mathrm{RG})+20 \% \mathrm{konsentrat;} \mathrm{B}=60 \%$ RG $+40 \%$ konsentrat; $C=30 \%$ RG $+30 \%$ kulit buah kakao $(\mathrm{KBK})+40 \%$ konsentrat; $\mathrm{D}=30 \% \mathrm{RG}+30 \% \mathrm{KBK}$ fermentasi $+40 \%$ konsentrat; $\mathrm{C}=30 \% \mathrm{RG}+50 \% \mathrm{KBK}$ fermentasi $+20 \%$ konsentrat. 
perlakuan C, D, dan E. Konsumsi protein yang rendah disebabkan oleh konsumsi bahan kering dan bahan organik (Tabel 4) dan kandungan protein yang lebih rendah (Tabel 3) dibandingkan perlakuan lain. Pemanfaatan kulit buah kakao fermentasi (perlakuan D dan E) meningkatkan kandungan protein ransum dan konsumsi pakan.

Efisiensi pemanfaatan nutrien tergantung pada kecukupan energi dan protein. Pemenuhan kebutuhan energi diarahkan pada kebutuhan energi untuk hidup pokok dan kebutuhan energi untuk produksi. Konsumsi energi berkisar 274-388 g ekor ${ }^{-1}$ hari ${ }^{-1}$. Standar kebutuhan TDN untuk kambing dengan bobot badan 10 $\mathrm{kg}$ dan PBB $100 \mathrm{~g}$ adalah $359 \mathrm{~g}$ (NRC, 1981) lebih besar daripada hasil penelitian Mandal et al. (2005), yaitu $331 \mathrm{~g}$ ekor $^{-1}$ hari $^{-1}$. Konsumsi energi perlakuan A lebih rendah $(\mathrm{P} \varangle$,05) dibanding perlakuan lain. Sejalan dengan konsumsi nutrien lain, konsumsi bahan kering yang rendah menyebabkan rendahnya konsumsi energi. Jumlah konsumsi energi merupakan kombinasi antara konsumsi bahan kering dengan kandungan energi ransum. Lallo (1996) melaporkan bahwa konsumsi energi meningkat sejalan dengan peningkatan kandungan energi pakan.

Kambing membutuhkan serat pakan yang cukup untuk aktivitas dan fungsi rumen yang normal. Serat pakan mengalami degradasi oleh mikroba yang berperan sebagai penyedia energi untuk mendukung hidup pokok, pertumbuhan, laktasi dan reproduksi (Lu et al., 2005). Kebutuhan serat dalam ransum kambing belum ditetapkan secara jelas dalam pedoman dan standar kebutuhan nutrisi. Rataan konsumsi serat kasar berkisar 109-157 g ekor $^{-1}$ hari $^{-1}$. Konsumsi serat kasar perlakuan B paling rendah dan perlakuan $\mathrm{E}$ paling tinggi. Perbedaan konsumsi ini disebabkan kandungan serat kasar dan proporsi bahan penyusun ransum yang berbeda. Penurunan konsumsi serat kasar ransum perlakuan A karena substitusi sebagian rumput gajah dengan penggunaan konsentrat yang memiliki kandungan serat kasar yang lebih rendah.

Peran serat pakan sebagai sumber energi erat kaitannya dengan proporsi penyusun komponen serat seperti selulosa, hemiselulosa dan lignin. Rataan konsumsi NDF sebesar $284 \mathrm{~g} \mathrm{ekor}^{-1}$ hari $^{-1}$ atau $40 \mathrm{~g} \mathrm{~kg}^{-1} \mathrm{BB}^{0,75}$ hari ${ }^{-1}$. Penelitian yang dilakukan Souza et al. (2009) menghasilkan konsumsi NDF oleh kambing sebesar $32 \mathrm{~g} \mathrm{~kg}^{-1}$ $\mathrm{BB}^{0,75}$ hari $^{-1}$. Kandungan NDF ransum menggambarkan jumlah komponen fraksi serat dinding sel yang terdapat dalam ransum yaitu hemiselulosa, selulosa dan lignin, dan jumlah tersebut dalam penelitian ini diperkirakan terlalu tinggi dalam menunjang perkembangan mikroba rumen yang optimum.

\section{Pertambahan Bobot Badan}

Pertumbuhan merupakan suatu indikator terjadinya proses deposisi nutrien dalam jaringan tubuh. Kemampuan retensi $\mathrm{N}$ protein ke dalam jaringan dipengaruhi oleh pasokan protein dan energi ransum. Rataan PBB kambing sebesar 81 g ekor $^{-1}$ hari ${ }^{-1}$. Hasil ini belum mencapai target $100 \mathrm{~g}_{\text {ekor }}{ }^{-1}$ hari $^{-1}$. Hal ini disebabkan konsumsi energi yang masih di bawah standar. Konsumsi protein yang telah memenuhi kebutuhan ternak kambing tidak diikuti dengan ketersediaan energi untuk pertumbuhan. Bobot badan awal ternak sebelum perlakuan berkisar 12,72-13,88 $\mathrm{kg}$ (Tabel 5) membutuhkan energi berkisar 392-405 g ekor-1 hari-1 (Tabel 6), sedangkan konsumsi energi pakan berkisar 274-388 g ekor $^{-1}$ hari $^{-1}$ (Tabel 4).

Kandungan protein kasar dan TDN ransum perlakuan (Tabel 3) telah memenuhi standar kebutuhan. Konsumsi bahan kering yang berkisar 57,95\%-75,26\% dari kebutuhan (Tabel 6) merupakan penyebab utama konsumsi protein dan energi yang rendah. Konsumsi bahan kering yang rendah disebabkan kandungan fraksi serat yang tinggi. Lu et al. (2005) menjelaskan bahwa kandungan ADF sebesar 18\% akan menghasilkan konsumsi bahan kering tertinggi dan menurun pada kandungan ADF lebih dari 18\%. Konsumsi bahan kering dan karbohidrat bukan serat (non-fiber carbohydrate, NFC) menurun secara linier dengan peningkatan kandungan NDF pakan (Zhao et al., 2011) karena peningkatan konsumsi fraksi serat akan meningkatkan aktivitas mengunyah (Lu et al., 2005).

Perlakuan D yang terdiri atas 30\% rumput gajah segar, 30\% KBK fermentasi, dan 40\% konsentrat menghasilkan PBB tertinggi, yaitu 102 g. Hasil ini lebih baik daripada hasil penelitian Tuah et al. (1995), yaitu sebesar 55 g pada tingkat penggunaan KBK $30 \%$ dalam ransum. Aregheore (2002) memperoleh PBB kambing yang diberi pakan berupa campuran beberapa hasil ikutan coklat

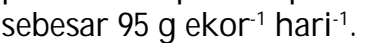

Tabel 5. Bobot badan awal, pertambahan bobot badan (PBB), dan konversi ransum kambing yang diberi perlakuan

\begin{tabular}{|c|c|c|c|c|c|}
\hline \multirow{2}{*}{ Nutrien } & \multicolumn{5}{|c|}{ Perlakuan } \\
\hline & A & B & $\mathrm{C}$ & $\mathrm{D}$ & $\mathrm{E}$ \\
\hline Bobot badan awal (kg) & $13,88 \pm 0,58$ & $12,72 \pm 1,14$ & $13,50 \pm 0,91$ & $13,73 \pm 1,06$ & $13,52 \pm 3,48$ \\
\hline Bobot badan akhir (kg) & $15,53 \pm 0,67$ & $14,88 \pm 1,29$ & $15,85 \pm 0,95$ & $16,58 \pm 1,11$ & $15,87 \pm 3,57$ \\
\hline Bobot badan metabolik (kg) & $7,19 \pm 0,23$ & $6,73 \pm 0,45$ & $7,04 \pm 0,36$ & $7,13 \pm 0,41$ & $7,02 \pm 1,34$ \\
\hline PBB (g ekor ${ }^{-1}$ hari $\left.^{-1}\right)$ & $58,95 \pm 3,09^{\mathrm{d}}$ & $77,38 \pm 5,46^{c}$ & $83,93 \pm 1,79^{\mathrm{b}}$ & $101,79 \pm 1,79^{a}$ & $83,93 \pm 3,09^{b}$ \\
\hline Konversi ransum & $7,38 \pm 0,51^{\mathrm{a}}$ & $6,45 \pm 0,63^{\mathrm{ab}}$ & $6,42 \pm 0,41^{\mathrm{ab}}$ & $5,50 \pm 0,47^{\mathrm{b}}$ & $6,77 \pm 1,20^{\mathrm{ab}}$ \\
\hline
\end{tabular}

Keterangan: Superskrip berbeda pada baris yang sama menunjukkan berbeda nyata $(\mathrm{P} \varangle, 05)$. A= 80\% rumput gajah (RG) $+20 \%$ konsentrat; $\mathrm{B}=60 \%$ RG $+40 \%$ konsentrat; $C=30 \%$ RG $+30 \% \mathrm{KBK}+40 \%$ konsentrat; $\mathrm{D}=30 \% \mathrm{RG}+30 \%$ kulit buah kakao (KBK) fermentasi $+40 \%$ konsentrat; $\mathrm{C}=30 \% \mathrm{RG}+50 \%$ KBK fermentasi $+20 \%$ konsentrat. 
Tabel 6. Estimasi kebutuhan bahan kering, protein kasar dan total digestible nutrient (TDN) untuk mencapai pertambahan bobot badan 100 g ekor $^{-1}$ hari $^{-1}$

\begin{tabular}{|c|c|c|c|c|c|}
\hline \multirow{2}{*}{ Peubah } & \multicolumn{5}{|c|}{ Perlakuan } \\
\hline & A & B & $\mathrm{C}$ & $\mathrm{D}$ & E \\
\hline Kebutuhan bahan kering $\left(\text { g ekor }^{-1} \text { hari }^{-1}\right)^{\mathrm{a}}$ & 749 & 716 & 738 & 745 & 738 \\
\hline \multicolumn{6}{|l|}{ Kebutuhan protein kasar } \\
\hline Bobot badan metabolik (kg BB $\left.{ }^{0,75}\right)$ & 7,19 & 6,73 & 7,04 & 7,13 & 7,02 \\
\hline CPm (g ekor ${ }^{-1}$ hari $\left.^{-1}\right)$ & 30 & 28 & 29 & 30 & 29 \\
\hline CPg $\left(\right.$ g ekor $^{-1}$ hari $\left.^{-1}\right)$ & 28 & 28 & 28 & 28 & 28 \\
\hline Kebutuhan protein (g ekor ${ }^{-1}$ hari $^{-1}$ ) & 58 & 56 & 58 & 58 & 58 \\
\hline \multicolumn{6}{|l|}{ Kebutuhan energi } \\
\hline TDNm ( g ekor $^{-1}$ hari $\left.^{-1}\right)$ & 203 & 190 & 198 & 201 & 188 \\
\hline TDNg $\left(\right.$ g ekor $^{-1}$ hari $^{-1}$ ) & 202 & 202 & 202 & 202 & 202 \\
\hline Kebutuhan TDN (g ekor ${ }^{-1}$ hari $^{-1}$ ) & 405 & 392 & 400 & 403 & 400 \\
\hline
\end{tabular}

Keterangan: $\mathrm{CPm}=$ kebutuhan protein untuk hidup pokok $\left(4,15 \mathrm{~g} \mathrm{~kg}^{-1} \mathrm{BB}^{0,75}\right) ; \mathrm{CPg}=$ kebutuhan protein untuk pertumbuhan $(0,284 \mathrm{~g}$ untuk setiap g pertambahan bobot badan); TDNm= kebutuhan TDN untuk hidup pokok $\left(28,19 \mathrm{~g} \mathrm{~kg}^{-1} \mathrm{BB}^{0,75}\right)$; TDNg=kebutuhan TDN untuk pertumbuhan $(2,02 \mathrm{~g}$ untuk setiap g pertambahan bobot badan) (NRC, 1981).

a $2,8(\%) \times \mathrm{BB}(\mathrm{kg})+0.36 \mathrm{~kg}(\mathrm{NRC}, 1981)$.

Pemanfaatan KBK fermentasi (D) memberikan hasil yang lebih baik dibanding pemanfaatan KBK (C) dan rumput gajah (B). Ketiga bahan itu memiliki proporsi sama $(30 \%)$ dalam ransum, namun memberikan PBB harian yang berbeda, yaitu 102; 84; dan 77 g masingmasing untuk perlakuan D, C, dan B. Hal ini disebabkan konsumsi (Tabel 4) dan komposisi kimia (Tabel 2) pakan perlakuan D yang lebih baik. Konsumsi bahan kering ransum D sebesar $560 \mathrm{~g}$ atau 75,26\% dari estimasi kebutuhan bahan kering $745 \mathrm{~g}$, lebih tinggi dibanding perlakuan lain. Konsumsi pakan yang masih di bawah kebutuhan memungkinan substrat tinggal lebih lama dalam rumen dan memberikan waktu yang lebih banyak bagi enzim untuk melakukan kontak dengan substrat.

Kehilangan terbesar bahan kering yang dikonsumsi terutama yang berasal dari hijauan dan hasil ikutan pertanian terjadi dalam feses (Coleman \& Moore, 2003). Proporsi bagian pakan yang hilang dan pemanfaatan lain mempengaruhi efisiensi pakan. Efisiensi pakan dapat diukur dengan efisiensi penggunaan pakan dan konversi pakan. Konversi pakan merupakan jumlah pakan yang dikonsumsi untuk menghasilkan satu unit produksi ternak (Katongole et al., 2009). Nilai konversi pakan yang makin kecil menunjukkan kualitas pakan yang makin baik. Konversi pakan percobaan berkisar 5,50-7,38. Hasil ini lebih baik dibandingkan konversi KBK pada ternak domba yang berkisar 12,23-17,74 (Lallo, 1996). Penelitian Aregoheore (2004) menghasilkan konversi pakan sebesar 14,90 pada ternak kambing yang diberi pakan daun ubi rambat. Besaran nilai konversi pakan sangat tergantung pada kecernaan dan metabolisme nutrisi dalam tubuh ternak. Pakan yang dikonsumsi oleh ternak akan digunakan untuk hidup pokok dan produksi. Konversi pakan perlakuan A lebih besar $(\mathrm{P} \varangle 0,05)$ dibanding perlakuan lain. Konversi terkecil $(5,50)$ dicapai oleh perlakuan $\mathrm{D}$.

\section{KESIMPULAN}

Pemanfaatan 30\% kulit buah kakao (KBK) fermentasi yang dikombinasikan dengan rumput gajah dan konsentrat menghasilkan konsumsi bahan kering (560 g ekor $^{-1}$ hari $\left.^{-1}\right)$, konversi ransum $(5,50)$ dan PBB (102 g ekor $^{-1}$ hari $^{-1}$ ) yang lebih baik dibandingkan dengan ransum yang hanya mengandung rumput gajah dan KBK tanpa fermentasi.

\section{DAFTAR PUSTAKA}

Abdou, A. R., E. Y. Eid, A. M. El-Essawy, A. M. Fayed, H. G. Helal, \& H.M. El-Shaer. 2011. Effect of feeding different sources of energy on performance of goats fed saltbush in Sinai. J. American Sci. 7(1):1040-1050.

Alemawor, F., V. P. Dzogbefia, E. O. K. Oddoye, \& J. H. Oidham. 2009. Effect of Pleurotus ostreatus fermentation on cocoa pod husk composition: Influence of fermentation period and $\mathrm{Mn}^{2+}$ supplemention on the fermentation process. Afr. J. Biotechnol. 8:1950-1958.

Aregheore, E. M. 2002. Chemical evaluation and digestibility of cocoa (Theobroma cacao) byproducts fed to goats. Trop. Anim. Health Prod. 34:339-348.

Aregheore, E. M. 2004. Nutritive value of sweet potato (Ipomea batatas (L) Lam) forage as goat feed: voluntary intake, growth and digestibility of mixed rations of sweet potato and batiki grass (Ischaemum aristatum var. indicum). Small Rumin. Res. 51:235-241.

Aregheore, E. M. 2006. Utilization of concentrate supplements containing varying levels of copra cake (Cocos nucifera) by growing goats fed a basal diet of napier grass (Pennisetum purpureum). Small Rumin. Res. 64:87-93.

Bonnen, A. M, L. H. Anton, \& A. B. Orth. 1994. Lignin-degrading enzymes of the commercial button mushroom, Agaricus bisporus. Appl. Environ. Microbiol. 60:960-965.

Coleman, S. W. \& J. E. Moore. 2003. Feed quality and animal performance. Field Crops Res. 84:17-29.

de Koker, T. H., K. K. Nakasone, J. Haarhof, H. H. Burdsall Jr., \& B. J. H Janse. 2003. Phylogenetic relationships of the 
genus Phanerochaete inferred from the internal transcribed spacer region. Mycol. Res. 107: 1032-1040

Fedele, V., S. Clapsa, R. Rubino, M. Calandrelli, \& A. M. Pilla. 2002. Effect of free-choice and traditional feeding systems on goat feeding behaviour and intake. Livest. Prod. Sci. 74:19-31.

Iyayi, E. A. 2004. Changes in the cellulose, sugar and crude protein contents of agro-industrial by-products fermented with Aspergillus niger, Aspergillus flavus and Penicillium sp. Afr. J. Biotechnol. 3:186-188.

Katongole, C. B., E. N. Sabiiti, F. B. Bareeba, \& I. Ledin. 2009. Performance of growing indigenous goat fed diet based on urban market crops wastes. Trop. Anim. Helath Prod. 41:329-336.

Kondo, M., K. Kita, \& H. Yokota. 2004. Feeding value to goats of whole-crop oat ensiled with green tea waste. Anim. Feed Sci. Technol. 113:71-81.

Lallo, C. H. O. 1996. Feed intake and nitrogen utilisation by growing goats fed by-product based diets of different protein and energy levels. Small Rumin. Res. 22:193-204.

Lewis, R. M. \& G. C. Emmans. 2010. Feed intake of sheep as affected by body weight, breed, sex, and feed composition. J. Anim. Sci. 88:467-480.

Lu, C. D., J. R. Kawas, \& O. G. Mahgoub. 2005. Fiber digestion and utilization in goats. Small Rumin. Res. 60:45-65.

Mandal, A. B., S. S. Paul, G. P. Mandal, A. Kannan, \& N. N. Pathak. 2005. Deriving nutrient requirements of growing Indian goats under tropical condition. Small Rumin. Res. 58: $201-217$

Moran, J. 2005. Tropical Dairy Farming. Landlinks Press. Collingwood.

Negesse, T., M. Rodehutscord, \& E. Pfeffer. 2001. The effect of dietary crude protein level on intake, growth, protein retention, and utilization of growing male Saanen kids. Small Rumin. Res.. 39:243-351.

NRC. 1981. Nutrient Requirements of Goats: Angora, Dairy, and Meat Goats in Temperate and Tropical Countries. National Academic Press, Washington, DC.

Shi, J., R. R. Sharma-Shivappa, \& M. S. Chin. 2009. Microbial pretreatmen of cotton stalk by submerged cultivation of Phanerochaete chrysosporium. Bioresour. Technol. 100:4388-4395.

Singh, D. \& S. Chen. 2008. The white-rot fungus Phanerochaete chrysosporium: conditions for the production of lig- nin-degrading enzymes. Appl. Microbiol. Biotechnol. 81:399-417.

Souza, E. J., A. Guima, Â. M. V. Batista, K. L. Santosa, J. R. Silva, N. A. P. Moraisa, \& A. F. Mustafac. 2009. Effects of soybean hulls inclusion on intake, total tract nutrient utilization and ruminal fermentation of goats fed spineless cactus (Opuntia ficus-indica Mill) based diets. Small Rumin. Res. 85: 63-69

Sun, Y. \& J. Cheng. 2002. Hydrolisis of lignocellulosic materials for ethanol production: a review. Bioresour. Technol. 83:1-11

Suparjo, K. G. Wiryawan, E. B. Laconi, \& D. Mangunwidjaja. 2009. Perubahan komposisi kimia kulit buah kakao akibat penambahan mangan dan kalsium dalam biokonversi dengan kapang Phanerochaete chrysosporium. Med. Pet. 32:204-211.

Takano, M., M. Nakamura, A. Nishida, \& M. Ishihara. 2004. Manganase peroxidase from Phanerochaete crassa WD1694. Bull. FFPRI 3(1):7-13.

Toharmat, T., E. Nursasih, R. Nazilah, N. Hotimah, T. Q. Noerzihad, N. A. Sigit, \& Y. Retnani. 2006. Sifat fisik pakan kaya serat dan pengaruhnya terhadap konsumsi dan kecernaan nutrien ransum pada kambing. Med. Pet. 29:146-154.

Tuah, A. K., F. Y. Obese, E. R. Orskov, D. B. Okai, D. Adomako, K. O. Amaning, A. N. Said, \& J. F. D. Greenhalgh. 1995. The performance of Djallonke sheep fed on diets containing various proportions of cocoa pod husk and 5\% NaOH-treated maize cobs. Anim Feed Sci Technol 5:269-279.

van Hao, N. \& I. Liden. 2001. Performance of growing goats fed Gliricidia maculata. Small Rumin. Res. 39:113-119.

Van, D. T. T., N. T. Mui, \& I. Ledin. 2005. Tropical foliages: effect of presentation method and species on intake by goats. Anim. Feed Sci. Technol. 118:1-17.

Yansari, T. A. T., R. valizadeh, A. Naserian, D. A. Christensen, P. Yu, \& F. E. Shahroodi. 2004. Effects of alfalfa particle size and spesific gravity on chewing activity, digestibility and performance of Holstein dairy cows. J. Dairy Sci. 87:3912-3924.

Zhao, X. H. T. Zhang, M. Xu, \& J. H. Yao. 2011. Effects of physically effective fiber on chewing activity, ruminal fermentation, and digestibility in goats. J. Anim. Sci. 89: 501-509. 